\title{
Review
}

\section{Cardiovascular Autonomic Dysfunction in Animal Models of Parkinson's Disease}

\author{
Sheila M. Fleming* \\ Department of Psychology and Neurology, University of Cincinnati, Cincinnati, OH, USA
}

\begin{abstract}
Cardiovascular autonomic dysfunction is a common non-motor symptom associated with synucleinopathies such as Parkinson's disease (PD). Several recent clinical studies indicate that cardiovascular autonomic impairments including orthostatic hypotension and sympathetic denervation may precede the development of the cardinal motor symptoms in PD, making cardiovascular dysfunction an attractive target for the development of biomarkers for early detection and potential neuroprotective strategies for PD. However, the pathologic mechanisms underlying cardiovascular dysfunction as well as many of the non-motor symptoms in PD remain unknown. This is likely due, in part, to an initial under-appreciation of PD as a systemic disorder as well as limited research in cardiovascular dysfunction in animal models of PD. Here, we highlight studies that have investigated cardiovascular dysfunction in rodent models of PD and the potential usefulness of genetic mouse models of PD for this endeavor.
\end{abstract}

Keywords: Alpha-synuclein, orthostatic hypotension, sympathetic denervation, baroreflex, heart rate variability, 6-hydroxydopamine, MPTP

\section{SYMPATHETIC AND PARASYMPATHETIC NERVOUS SYSTEM DYSFUNCTION IN PARKINSON'S DISEASE}

The interaction between the sympathetic and parasympathetic divisions of the autonomic system plays a critical role in control of heart rate and blood pressure with alterations in either system leading to impaired cardiovascular function. The sympathetic division is important for mobilizing the body for selective energy expenditure and is associated with the "fight or flight" response. In the brainstem the rostral ventrolateral medulla regulates the sympathetic nervous system. Sympathetic activation results in increased heart rate and blood pressure, pupil dilation, and sweating. Norepinephrine is the main neurotransmitter related with increased heart rate

*Correspondence to: Sheila Fleming, Ph.D., Department of Psychology and Neurology, University of Cincinnati, One Edwards 5120H, Cincinnati, OH 45221, USA. Tel.: +1 513558 7026; Fax: +1 513556 4168; E-mail: fleminsa@ucmail.uc.edu. and blood pressure (acetylcholine is associated with increased sweating). In contrast, the parasympathetic division is related with reduced energy expenditure and increased energy conservation, "rest and digest". The vagus nerve drives parasympathetic activation and promotes gastrointestinal processes, fat storage, and pupil constriction. Acetylcholine is the main neurotransmitter of the parasympathetic division. Both systems interact with the baroreceptor reflex to tightly regulate blood pressure.

Impaired autonomic control of cardiovascular function is associated with neurodegenerative disorders such as the synucleinopathies. Synucleinopathies are diseases characterized by the development of alpha-synuclein containing Lewy bodies and neurodegeneration and include Parkinson's disease (PD), multiple system atrophy, and demetia with Lewy bodies [1]. In PD, the most common synucleinopathy, impairments in cardiovascular autonomic function are frequently observed and manifest in a range of cardiovascular alterations in patients (Table 1). The noradrenergic aspect of the sympathetic nervous 
Table 1

Cardiovascular autonomic dysfunction in PD

\begin{tabular}{|c|c|c|}
\hline Synucleinopathy & Cardiovascular autonomic dysfunction & Associated pathology \\
\hline Parkinson's disease & $\begin{array}{l}\text { Orthostaic hypotension, syncope, impaired } \\
\text { baroreflex, reduced heart rate variability, } \\
\text { post-prandial hypotension, hypertension } \\
\text { while supine }\end{array}$ & $\begin{array}{l}\text { Post-ganglionic lesions, Cardiac sympathetic } \\
\text { denervation, abnormal alpha-synuclein accumulation } \\
\text { in sympathetic ganglia, Lewy bodies in periphery } \\
\text { (stellate ganglia and cardiac plexus) and centrally } \\
\text { (locus coeruleus, medulla, hypothalamus) }\end{array}$ \\
\hline Multiple System Atrophy & $\begin{array}{l}\text { Orthostatic hypotension, post-prandial } \\
\text { hypotension, supine hypetension }\end{array}$ & Pre-ganglionic sympathetic lesions \\
\hline Dementia with Lewy Bodies & Syncope, Orthostatic hypotension & Sympathetic denervation, Cardiovagal denervation \\
\hline
\end{tabular}

system is particularly affected in PD. For example, profound sympathetic noradrenergic denervation has been shown functionally by measuring myocardial ${ }^{123}$ I-metaiodobenzylguanidine (MIBG, an analogue of norepinephrine) and $6-\left[{ }^{18} \mathrm{~F}\right]$ fluorodopamine uptake in peripheral adrenergic nerves in PD patients [2, 3]. This has been verified anatomically through tyrosine hydroxylase immunohistochemistry of postganglionic cardiac sympathetic nerves of PD patients [4]. Interestingly, this decrease in tyrosine immunoreactivity in postganglionic cardiac sympathetic nerves is not seen in multiple system atrophy, another synucleinopathy with symptoms of autonomic dysfunction, and provides a method to differentiate the two diseases, which can be difficult to do based on symptoms, especially in the early stages [4]. Autonomic tests such as the Valsalva maneuver and head up tilt can detect baroreflex failure and orthostatic hypotension in PD patients [5-7]. Orthostatic hypotension, an uncompensated fall in systolic blood pressure after assuming an upright position, is reported to occur in $\sim 10-40 \%$ of PD patients and is associated with progressive cardiac sympathetic denervation [3, 8]. Orthostatic hypotension is a particularly dangerous condition in PD because it can contribute to falls which patients are already susceptible to. Furthermore, orthostasis is notoriously under-reported by patients having unexplained falls in PD. Alterations in heart rate variability measures have also been observed in PD $[9,10]$ and electrocardiographic assessment of heart rate variability has been proposed as a potential screen for those at risk of developing PD [11].

\section{EARLY SYMPTOMATOLOGY}

Recent clinical studies suggest that many of the non-motor symptoms associated with PD may develop early in the disease, prior to the onset of the cardinal motor symptoms. Indeed, neurocardiological alterations have been reported to occur early in several of the synucleinopathies [12-15]. For example, both orthostatic hypotension and cardiac sympathetic denervation have been shown to develop before diagnosis of PD in some cases [15, 16]. Both Orimo et al. [17] and Fujishiro et al. [18] found that cardiac sympathetic denervation and alpha-synuclein pathology occur in Incidental Lewy Body disease, which is thought to reflect pre-manifest PD [19]. In addition to their early development, cardiovascular alterations have also been linked with other non-motor symptoms including olfaction, cognition, and sleep dysfunction [20-23]. This suggests cardiovascular autonomic dysfunction could be a useful biomarker for detecting the early stages of the disease as well as a target for potential therapeutics.

\section{PERIPHERAL AND CENTRAL NERVOUS SYSTEM PATHOLOGY}

While synucleinopathies are typically characterized by neuronal degeneration of specific cell types such as nigrostriatal dopamine neuron loss in PD, there is considerable widespread central and peripheral nervous system pathology that likely contributes to the nonmotor symptoms such as cardiovascular autonomic dysfunction [19, 24-26]. In addition to nigrostriatal neuronal death in PD, there is also cell loss in the catecholaminergic $\mathrm{C} 1$ region in the ventrolateral medulla and in noradrenergic neurons in the locus coeruleus, areas important for blood pressure regulation [27]. Lewy bodies that contain alpha-synuclein are observed in central and peripheral regions associated with cardiovascular autonomic function such as the medulla, locus coeruleus, cardiac plexus, and stellate ganglia [19, 24-27]. Furthermore, patients with a familial form of PD associated with duplication or triplication of the alpha-synuclein locus show impaired parasympathetic function in the valsalva maneuver and reduced cardiac sympathetic innervation suggesting an important role for alpha-synuclein in the pathogenesis of sympathetic and parasympathetic dysfunction in PD $[28,29]$. Mechanistically, Orimo et al. [30] showed in 
Table 2

Cardiovascular autonomic dysfunction in rodent models of PD

\begin{tabular}{|c|c|c|}
\hline Model & Dysfunction & References \\
\hline 6-OHDA & $\downarrow$ nocturnal heart rate, attenuated baroreflex response & {$[37,44]$} \\
\hline МРТP & $\begin{array}{l}\text { Reduced }{ }^{125} \text { I-MIBG uptake, NE turnover, NE transporter density, preserved } \\
\text { myocardial nerve fibers, } \\
\text { depressed contractility }\end{array}$ & {$[46,47,49,50]$} \\
\hline $\begin{array}{l}\text { Overexpression of } \\
\text { Alpha-Synuclein in Mouse }\end{array}$ & $\begin{array}{l}\downarrow \text { NE-induced contraction (aortic ring preparation), Impaired baroreceptor } \\
\text { control of heart rate }\end{array}$ & {$[62,75,76]$} \\
\hline
\end{tabular}

sympathetic ganglia from PD patients that degeneration of the cardiac sympathetic nerves precedes neuron loss in parvertebral sympathetic ganglia and that pathological alpha-synuclein is found in the distal axons in the earlier stages of the disease and as the disease progresses pathological alpha-synuclein can be found more in the soma [30]. Most recently the same group showed that unmyelinated axons of cardiac nerves are more susceptible to degeneration than myelinated axons and this is also associated with more accumulation of alpha-synuclein in unmyelinated axons [31].

\section{CARDIOVASCULAR AUTONOMIC DYSFUNCTION AND ANIMAL MODELS OF PD 6-HYDROXYDOPAMINE (6-OHDA)}

The toxicity of 6-OHDA is specific to catecholaminergic cells and is widely used to create animal models of Parkinson's disease [32-35]. 6-OHDA injected into the striatum, substantia nigra pars compacta, or medial forebrain bundle results in the destruction of dopaminergic neurons [32, 36]. The norepinephrine uptake blocker desipramine is often administered prior to nigra and medial forebrain bundle injections to create a selective dopaminergic lesion. These selective lesions have been used to study whether nigrostriatal dopamine cell loss can disrupt cardiovascular autonomic function. Indeed, intracerebral (medial forebrain bundle)administration of 6-OHDA in the rat does attenuate striatal dopamine release following acute increased blood pressure (phenylephrine administration) or decreased blood pressure (carotid occlusion) and reduces baroreflex sensitivity [37]. Sinoaortic denervation in the rat, a technique that has been used to study the role of the baroreflex in cardiovascular regulation [38], has also been used to study whether disruption of the baroreflex can enhance toxicity of specific PD-related neurotoxins such as 6-OHDA and rotenone. While sinoaortic denervation does not potentiate the effects of intracerebral 6-OHDA or systemic rotenone in the rat, sinaortic denervation does lead to decreased tyrosine hydroxylase activity in the striatum and substantia nigra [39-41]. Interestingly, injections of 6-OHDA to the neighboring ventral tegmental area alters circadian blood pressure regulation [42, 43]. Similarly, decreased nocturnal heart rate was observed in rats with unilateral 6-hydroxydopamine medial forebrain bundle lesions [44]. The 6-hydroxydopamine studies suggest a reciprocal relationship between midbrain dopamine pathways and cardiovascular parameters including blood pressure and heart rate (Table 2).

\section{1-METHY-4-PHENYL-1,2,3,6- TETRAHYDROPYRIDINE (MPTP)}

Similar to 6-OHDA, MPTP is a neurotoxin commonly used to model aspects of PD in animals. Systemic administration of MPTP results in reduced cardiac norepinephrine in rats and mice [45]. More recently Fukumitsu et al. showed reduced ${ }^{125} \mathrm{I}$-metaiodobenzylguanidine uptake, norepinephrine turnover, and norepinephrine transporter density in mice treated with MPTP [46-48]. Studies in MPTP-treated mice also show preserved myocardial nerve fibers and altered cardiac contractile function [49, 50]. These studies highlight that MPTP in the mouse not only alters central catecholamine systems it also has a profound effect on peripheral cardiac monoamine systems as well (Table 2). In contrast, in non-human primates, MPTP induces phasic peripheral catecholaminergic dysfunction followed by full recovery [51].

\section{GENETIC MOUSE MODELS}

With the discovery over the past 14 years of novel genes associated with familial forms of PD has come the development of novel genetic mouse models of Parkinsonism. These models may be particularly useful for studying the non-motor symptoms of PD and potential early markers of the disease. Cardiovascular autonomic dysfunction has been identified in PD patients with mutations or multiplication of the alpha- 
Table 3

Heart rate responses (bpm) in awake wildtype and Thy1-aSyn mice

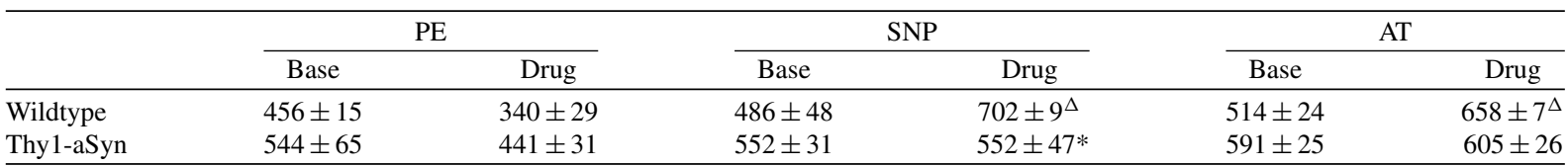

Wildtype and Thy1-aSyn mice were equipped with arterial telemetry at 3-5 months of age $(n=3-5$ per genotype). bpm $=$ beats per minute, $\mathrm{PE}=$ phenylephrine $(3 \mathrm{mg} / \mathrm{kg}, \mathrm{ip}), \mathrm{SNP}=$ sodium nitroprusside $(1 \mathrm{mg} / \mathrm{kg}$, ip $), \mathrm{AT}=$ atropine $(1 \mathrm{mg} / \mathrm{kg}, \mathrm{ip}) .{ }^{\Delta}$ represents $p<0.05 \mathrm{compared}$ to wildtype baseline, *represents $p<0.05$ compared to wildtype drug, $2 \times 2$ mixed design ANOVA, Fisher's LSD post hoc.

synuclein gene and in patients withmutations in the leucine-rich repeat kinase 2 gene [52-54].

While the presynaptic protein alpha-synuclein is associated with both sporadic and familial forms of the PD the function of alpha-synuclein remains unclear [55-59]. In the brain it is involved in synaptic function, vesicular handling, and synaptic plasticity $[60$, 61]. Work by Braak and colleagues suggests alphasynuclein pathology in brain regions outside of the substantia nigra, such as the medulla, locus coeruleus, and olfactory regions, may precede the development of alpha-synuclein pathology in the subtstantia nigra and provides a potential link between non-motor impairments and alpha-synuclein pathology in PD [19].

Mice overexpressing wildtype or mutated forms of alpha-synuclein may be particularly promising models to study cardiovascular autonomic dysfunction given the recent work by Orimo and colleagues highlighting the development of pathological alpha-synuclein accumulation and cardiac sympathetic denervation [30,31]. Alpha-synuclein is found in mouse sympathetic nerves innervating the aorta and is associated with contractility suggesting alpha-synuclein mouse models may be useful in elucidating potential underlying mechanisms of cardiovascular dysfunction in PD [62].

There are currently numerous mouse models of alpha-synuclein overexpression and while most do not develop the characteristic loss of nigrostriatal dopamine neurons several do show non-motor impairments such as gastrointestinal dysfunction, cognitive dysfunction, and altered emotional reactivity [63-67]. However, most have not assessed or found cardiovascular autonomic dysfunction in mutant mice. For example, Kuo et al. [67] showed autonomic abnormalities in the enteric nervous system of mice with A53T and $\mathrm{A} 30 \mathrm{P}$ mutations in alpha-synuclein but these mice did not develop cardiovascular dysfunction.

Based on the compelling relationship between alpha-synuclein pathology and cardiovascular dysfunction in PD we have begun to characterize mice overexpressing wildtype, human alpha-synuclein under the Thy 1 promoter (Thy1-aSyn) [68]. These mice show increased alpha-synuclein levels throughout the brain and develop proteinase K-resistant alpha-synuclein aggregates in several brain regions, including the substantia nigra, locus coeruleus, and olfactory bulb [68-70]. Thy1-aSyn mice show progressive impairments in sensorimotor function and non-motor impairments reminiscent of those observed in PD such as deficits in gastrointestinal function, olfaction, cognitive, and neuropsychiatric dysfunction [70-73]. By 14 months, these mice show a significant decrease in striatal dopamine and L-Dopa responsive behavioral deficits, indicating they reproduce important characteristic features of PD [74]. This suggests these mice may have functional impairments in cardiovascular autonomic function similar to those observed in PD. We measured baroreceptor control of heart rate in both anesthetized and awake Thy1-aSyn and wildtype mice in response to transiently increased and decreased blood pressure. Mice were administered the alpha 1-adrenergic agonist phenylephrine, the nitric oxide donor sodium nitroprusside, and the muscarinic antagonist atropine and blood pressure and heart rate responses were recorded. In response to the vasodilator sodium nitroprusside, anesthetized and awake wildtype mice displayed the characteristic tachycardic response to the sudden drop in blood pressure, while Thy1-aSyn mice showed no significant change in heart rate during an equivalent transient decrease in systolic blood pressure [75-76]. Similarly in PD patients, a blunted heart rate increase has been reported in response to the feet down tilt maneuver $[12,77]$. In addition to nitroprusside, Thy-aSyn mice showed a similar abnormal response to atropine, where heart rate increased in wildtype but not in Thy1aSyn mice (Table 3). These findings are important because they provide a foundation for future studies aimed at identifying brain structures and pathological mechanisms associated with cardiovascular autonomic dysfunction in PD. In addition, these results underscore the usefulness of alpha-synuclein overexpressing mice in the study of non-motor symptoms associated with PD. 


\section{CONCLUSION}

Cardiovascular autonomic dysfunction is a common non-motor symptom seen in the synucleinopathies. The majority of studies aimed at characterizing and understanding the pathology associated with cardiovascular dysfunction in these diseases has been performed primarily in patients and surprisingly work in animal models has been sparse. However, given the high prevalence of these symptoms and the potential early development of cardiovascular autonomic dysfunction in synucleinopathies, studies in animal models could be particularly valuable at this point. Combinations of toxin, genetic, and viral animal models would allow mechanistic approaches to understanding the etiology of cardiovascular autonomic dysfunction. In addition, models that display multiple nonmotor symptoms would be useful in understanding the relationship between symptoms that are correlated with each other such as olfaction and cardiovascular dysfunction. Furthermore, nonmotor symptoms that are unmet medical needs, such as cardiovascular autonomic dysfunction, are important targets for novel treatments and thus, make these models useful for preclinical studies of novel treatments for PD.

\section{ACKNOWLEDGMENTS}

The author's studies in this area have been funded by the Morris K. Udall Center of Excellence at UCLA (P50NS38367), the American Parkinson Disease Association UCLA Center of Excellence, and the Gardner Family Center for Parkinson's Disease and Movement Disorders at University of Cincinnati.

\section{REFERENCES}

[1] Trojanowski JQ, \& Lee VM (2003) Parkinson's disease and related alpha-synucleinopathies arebrain amyloidoses. Ann $N$ Y Acad Sci, 991, 107-110.

[2] Amino T, Orimo S, Itoh Y, Takahashi A, Uchihara T, \& Mizusawa H (2005) Profound cardiac sympathetic denervation occurs in Parkinson disease. Brain Pathol, 15, 29-34.

[3] Goldstein DS, Holmes CS, Dendi R, Bruce SR, Li ST (2002) Orthostatic hypotension from sympathetic denervation in Parkinson's disease. Neurology, 58, 1247-1255.

[4] Orimo S, Oka T, Miura H, Tsuchiya K, Mori F, Wakabayashi K, Nagao T, \& Yokochi M (2002) Sympathetic cardiac denervation in Parkinson's disease and pure autonomic failure but not in multiple system atrophy. J Neurol Neurosurg Psychiatry, 73, 776-777.

[5] Goldstein DS, Eldadah BA, Holmes C, Pechnik S, Moak J, Saleem A, \& Sharabi Y (2005) Neurocirculatory abnormalities in Parkinson disease with orthostatic hypotension:
Independence from levodopa treatment. Hypertension, 46, 1333-1339.

[6] Schmidt C, Herting B, Prieur S, Junghanns S, Schweitzer K, Globas C, Schöls L, Reichmann H, Berg D, \& Ziemssen T (2009) Valsalva manoeuvre in patients with different Parkinsonian disorders. J Neural Transm, 116, 875-880.

[7] Plaschke M, Trenkwalder P, Dahlheim H, Lechner C, \& Trenkwalder C (1998) Twenty-four-hour blood pressure profile and blood pressure responses to head-up tilt tests in Parkinson's disease and multiple system atrophy. J Hypertens, 16, 1433-1441.

[8] Biaggioni I (2007) Parkinson's disease: Autonomic neuronopathy with impaired cardiovascular regulation. Hypertension, 49, 21-22.

[9] Buob A, Winter H, Kindermann M, Becker G, Möller JC, Oertel WH, \& Böhm M (2010) Parasympathetic but not sympathetic cardiac dysfunction at early stages of Parkinson's disease. Clin Res Cardiol, 9, 701-706.

[10] Rahman F, Pechnik S, Gross D, Sewell L, \& Goldstein DS (2011) Low frequency power of heart ratevariability reflects baroreflex function, not cardiac sympathetic innervation. Clin Auton Res, 21, 133-141.

[11] Valappil RA, Black JE, Broderick MJ, Carrillo O, Frenette E, Sullivan SS, Goldman SM, Tanner CM, \& Langston JW (2010) Exploring the electrocardiogram as a potential tool to screen for premotor Parkinson's disease. Mov Disord 25 2296-2303.

[12] Barbic F, Perego F, Canesi M, Gianni M, Biagiotti S, Costantino G, Pezzoli G, Porta A, Malliani A, \& Furlan R (2007) Early abnormalities of vascular and cardiac autonomic control in Parkinson's disease without orthostatic hypotension. Hypertension, 49, 120-126.

[13] Kaufmann H, Nahm K, Purohit D, \& Wolfe D (2004) Autonomic failure as the initial presentation of Parkinson disease and dementia with Lewy bodies. Neurology, 63, 1093-1095.

[14] Minguez-Castellanos A, Chamorro CE, Escamilla-Sevilla F, Ortega-Moreno A, Rebollo AC, Gomez-Rio M, Concha A, \& Munoz DG (2007) Do alpha-synuclein aggregates in autonomic plexuses predate Lewy body disorders?: A cohort study. Neurology, 68, 2012-2018.

[15] Goldstein DS, Sharabi Y, Karp BI, Bentho O, Saleem A, Pacak K, \& Eisenhofer G (2009) Cardiac sympathetic denervation preceding motor signs in Parkinson disease. Cleve Clin J Med, Suppl 2, S47-50.

[16] Goldstein DS (2006) Orthostatic hypotension as an early finding in Parkinson's disease. Clin Auton Res, 16, $46-54$.

[17] Orimo S, Takahashi A, Uchihara T, Mori F, Kakita A, Wakabayashi K, \& Takahashi H (2007) Degeneration of cardiac sympathetic nerve begins in the early disease process of Parkinson's disease. Brain Pathol, 17, 24-30.

[18] Fujishiro H, Frigerio R, Burnett M, Klos KJ, Josephs KA, Delledonne A, Parisi JE, Ahlskog JE, \& Dickson DW (2008) Cardiac sympathetic denervation correlates with clinical and pathologic stages of Parkinson's disease. Mov Disord, 23, 1085-1092.

[19] Braak H, Del Tredici K, Rub U, de Vos RA, Jansen Steur EN, \& Braak E (2003) Staging of brain pathology related to sporadic Parkinson's disease. Neurobiol Aging, 24, 197-211.

[20] Iijima M, Osawa M, Momose M, Kobayakawa T, Saito S, Iwata M, \& Uchiyama S (2010) Cardiac sympathetic degeneration correlates with olfactory function in Parkinson's disease. Mov Disord, 25, 1143-1149.

[21] Kim JS, Shim YS, Song IU, Yoo JY, Kim HT, Kim YI, \& KS Lee (2009) Cardiac sympathetic denervation and its 
association with cognitive deficits in Parkinson's disease. Parkinsonism Relat Disord, 15, 706-708.

[22] Peralta C, Stampfer-Kountchev M, Karner E, Köllensperger M, Geser F, Wolf E, Seppi K, Benke T, Poewe W, \& Wenning GK (2007) Orthostatic hypotension and attention in Parkinson's disease with and without dementia. J Neural Transm, 114, 585-588.

[23] Postuma RB, Lanfranchi PA, Blais H, \& Gagnon JF, Montplaisir JY (2010) Cardiac autonomic dysfunction in idiopathic REM sleep behavior disorder. Mov Disord, 25, 2304-2310.

[24] Forno LS, \& Norville RL (1976) Ultrastructure of Lewy bodies in the stellate ganglion. Acta Neuropathol (Berl), 34, 183-197.

[25] Rajput AH, \& Rozdilsky B (1976) Dysautonomia in Parkinsonism: A clinicopathological study. J Neurol Neurosurg Psychiatry, 39, 1092-1100.

[26] Iwanaga K, Wakabayashi K, Yoshimoto M, Tomita I, Satoh H, Takashima H, Satoh A, Seto M, Tsujihata M, \& Takahashi H (1999) Lewy body-type degeneration in cardiac plexus in Parkinson's and incidental Lewy body diseases. Neurology, 52, 1269-1271.

[27] Gai WP, Geffen LB, Denoroy L, \& Blessing WW (1993) Loss of $\mathrm{C} 1$ and $\mathrm{C} 3$ epinephrine-synthesizing neurons in the medulla oblongata in Parkinson's disease. Ann Neurol, 33, 357367.

[28] Singleton A, Gwinn-Hardy K, Sharabi Y, Li ST, Holmes C, Dendi R, Hardy J, Singleton A, Crawley A, \& Goldstein DS (2004) Association between cardiac denervation and parkinsonism caused by alpha-synuclein gene triplication. Brain, 127, 768-772.

[29] Orimo S, Uchihara T, Nakamura A, Mori F, Ikeuchi T, Onodera O, Nishizawa M, Ishikawa A, Kakita A, Wakabayashi K, \& Takahashi H (2008a) Cardiac sympathetic denervation in Parkinson's disease linked to SNCA duplication. Acta Neuropathol, 116, 575-577.

[30] Orimo S, Uchihara T, Nakamura A, Mori F, Kakita A, Wakabayashi K, \& Takahashi H (2008b) Axonal alpha-synuclein aggregates herald centripetal degeneration of cardiac sympathetic nerve in Parkinson's disease. Brain, 131, 642-650.

[31] Orimo S, Uchihara T, Kanazawa T, Itoh Y, Wakabayashi K, Kakita A, \& Takahashi H (2011) Unmyelinated axons are more vulnerable to degeneration than myelinated axons of the cardiac nerve in Parkinson's disease. Neuropathol Appl Neurobiol, 37, 791-802.

[32] Ungerstedt U (1968) 6-Hydroxy-dopamine induced degeneration of central monoamine neurons. European Journal of Pharmacology, 5, 107-110.

[33] Ungerstedt U (1971) Adipsia and aphagia after 6hydroxydopamine induced degeneration of the nigro-striatal dopamine system. Act Physiol Scand Suppl, 367, 95-122.

[34] Kostrzewa RM, \& Jacobwitz DM (1974) Pharmacological actionsof 6-hydroxydopamine. Pharmacological Review, 26, 199-288.

[35] Schallert T, Wilcox RE (1985) Neurotransmitter-selective brain lesions. In Neuromethods (Series 1: Neurochemistry), General Neurochemical Techniques (Boulton A. A. and Baker G. B., Eds.), Humana Press, Totowa, NJ. 343-387.

[36] Kirik D, Rosenblad C, \& Bjorklund A (1998) Characterization of behavioral and neurodegenerative changes following partial lesions of the nigrostriatal dopamine system induced by intrastriatal 6-hydroxydopamine in the rat. Experimental Neurology, 152, 259-277.

[37] Lu SF, Young HJ, \& Lin MT (1995) Nigrostriatal dopamine system mediates baroreflex sensitivity in rats. Neurosci Lett, 190, $17-20$.
[38] Krieger EM (1967) Effect of sinoaortic denervation on cardiac output. Am J Physiol, 213, 139-142.

[39] Alexander N, Hirata Y, \& Nagatsu T (1984) Reduced tyrosine hydroxylase activity in nigrostriatal system of sinoaorticdenervated rats. Brain Res, 299, 380-382.

[40] Alexander N, Nakahara D, Ozaki N, Kaneda N, Sasaoka T, Iwata N, \& Nagatsu T (1988) Striatal dopamine release and metabolism in sinoaortic-denervated rats by in vivo microdialysis. Am J Physiol, 254, R396-R399.

[41] Yu JG, Wu J, Shen FM, Cai GJ, Liu JG, \& Su DF (2008) Arterial baroreflex dysfunction fails to mimic Parkinson's disease in rats. J Pharmacol Sci, 108, 56-62.

[42] Sei H, Ikemoto K, Arai R, \& Morita Y (1999) Injection of 6hydroxydopamine into the ventral tegmental area suppresses the increase in arterial pressure during REM sleep in the rat. Sleep Res Online, 2, 1-6.

[43] Sakata M, Sei H, Toida K, Fujihara H, Urushihara R, \& Morita $Y(2002)$ Mesolimbic dopaminergic system is involved in diurnal blood pressure regulation. Brain Res, 928, 194201.

[44] Slack K, Billing R, Matthews S, Allbutt HN, Einstein R, \& Henderson JM (2010) Subtle cardiovascular dysfunction in the unilateral 6-hydroxydopamine-lesioned rat. Parkinsons Dis, 2010, 1-10.

[45] Fuller RW, Hahn RA, Snoddy HD, \& Wikel JH (1984) Depletion of cardiac norepinephrine in rats and mice by 1-methyl-4-phenyl-1,2,3,6-tetrahydropyridine (MPTP). Biochem Pharmaco, 133, 2957-2960.

[46] Fukumitsu N, Suzuki M, Fukuda T, Kiyono Y, Kajiyama S, \& Saji H (2006) Reduced 125I-meta-iodobenzylguanidine uptake and norepinephrine transporter density in the hearts of mice with MPTP-induced parkinsonism. Nucl Med Biol, 33, $37-42$

[47] Fukumitsu N, Suzuki M, Fukuda T, \& Kiyono Y (2009) Multipoint analysis of reduced (125)I-meta-iodobenzylguanidine uptake and norepinephrine turnover in the hearts of mice with 1-methyl-4-phenyl-1,2,3,6-tetrahydroxypyridineinduced parkinsonism. Nucl Med Biol, 36, 623-629.

[48] Takatsu H, Nishida H, Matsuo H, Watanabe S, Nagashima K, Wada H, Noda T, Nishigaki K, \& Fujiwara H (2000) Cardiac sympathetic denervation from the early stage of Parkinson's disease: Clinical and experimental studies with radiolabeled MIBG. J Nucl Med, 41, 71-77.

[49] Ren J, Porter JE, Wold LE, Aberle NS, Muralikrishnan D, \& Haselton JR (2004) Depressed contractile function and adrenergic responsiveness of cardiac myocytes in an experimental model of Parkinson disease, the MPTP-treated mouse. Neurobiol Aging, 25, 131-138.

[50] Amino T, Uchihara T, Tsunekawa H, Takahata K, Shimazu S, Mizusawa H, \& Orimo S (2008) Myocardial nerve fibers are preserved in MPTP-treated mice, despite cardiac sympathetic dysfunction. Neurosci Res, 60, 314-318.

[51] Goldstein DS, Li ST, Holmes C, \& Bankiewicz K (2003) Sympathetic innervation in the 1-methyl-4-phenyl-1,2,3,6tetrahydropyridine primate model of Parkinson's disease. $J$ Pharmacol Exp The, 306, 855-860.

[52] Singleton A, Gwinn-Hardy K, Sharabi Y, Li ST, Holmes C, Dendi R, Hardy J, Singleton A, Crawley A, \& Goldstein DS (2004) Association between cardiac denervation and parkinsonism caused by alpha-synuclein gene triplication. Brain, 127, 768-772.

[53] Goldstein DS, Imrich R, Peckham E, Holmes C, Lopez G, Crews C, Hardy J, Singleton A, \& Hallett M (2007) Neurocirculatory and nigrostriatal abnormalities in Parkinson disease from LRRK2 mutation. Neurology, 69, 1580-1584. 
[54] Tijero B, Gomez-Esteban JC, Llorens V, Lezcano E, Gonzalez-Fernández MC, de Pancorbo MM, Ruiz-Martinez J, Cembellin JC, \& Zarranz JJ (2010) Cardiac sympathetic denervation precedes nigrostriatal loss in the E46K mutation of the alpha-synuclein gene (SNCA). Clin Auton Res, 20, 267-269.

[55] Polymeropoulos MH, Lavedan C, Leroy E, Ide SE, Dehejia A, Dutra A, Pike B, Root H, Rubenstein J, Boyer R, Stenroos ES, Chandrasekharappa S, Athanassiadou A, Papapetropoulos T, Johnson WG, Lazzarini AM, Duvoisin RC, Di Iorio G, Golbe LI, \& Nussbaum RL (1997) Mutation in the alpha-synuclein gene identified in families with Parkinson's disease. Science, 276, 2045-2047.

[56] Kruger R, Kuhn W, Muller T, Woitalla D, Graeber M, Kosel S, Przuntek H, Epplen JT, Schols L, \& Riess O (1998) Ala30Pro mutation in the gene encoding alpha-synuclein in Parkinson's disease. Nat Genet, 18, 106-108.

[57] Singleton AB, Farrer M, Johnson J, Singleton A, Hague S, Kachergus J, Hulihan M, Peuralinna T, Dutra A, Nussbaum R, Lincoln S, Crawley A, Hanson M, Maraganore D, Adler C, Cookson MR, Muenter M, Baptista M, Miller D, Blancato J, Hardy J, \& Gwinn-Hardy K (2003) alpha-Synuclein locus triplication causes Parkinson's disease. Science, 302, 841.

[58] Chartier-Harlin MC, Kachergus J, Roumier C, Mouroux V, Douay X, Lincoln S, Levecque C, Larvor L, Andrieux J, Hulihan M, Waucquier N, Defebvre L, Amouyel P, Farrer M, \& Destee A (2004) Alpha-synuclein locus duplication as a cause of familial Parkinson's disease. Lancet, 364, 1167-1169.

[59] Spillantini MG, Schmidt ML, Lee VM, Trojanowski JQ, Jakes R, \& Goedert M (1997) Alpha-synuclein in Lewy bodies. Nature, 388, 839-840.

[60] Lotharius J, \& Brundin P (2002) Pathogenesis of Parkinson's disease: Dopamine, vesicles and alpha-synuclein. Nat Rev Neurosci, 3, 932-942.

[61] Nemani VM, Lu W, Berge V, Nakamura K, Onoa B, Lee MK, Chaudhry FA, Nicoll RA, \& Edwards RH (2010) Increased expression of alpha-synuclein reduces neurotransmitter release by inhibiting synaptic vesicle reclustering after endocytosis. Neuron, 65, 66-79.

[62] Marrachelli VG, Miranda FJ, Alabadí JA, Milán M, CanoJaimez M, Kirstein M, Alborch E, Fariñas I, \& Pérez-Sánchez F (2010) Perivascular nerve fiber $\alpha$-synuclein regulates contractility of mouse aorta: A link to autonomic dysfunction in Parkinson's disease. Neurochem Int, 56, 991-998.

[63] Wang L, Fleming SM, Chesselet M-F, \& Taché Y (2008) Abnormal colonic motility in mice overexpressing human wildtype alpha-synuclein. NeuroReport, 19, 873-876.

[64] George S, van den Buuse M, San Mok S, Masters CL, Li QX, \& Culvenor JG (2008) Alpha-synuclein transgenic mice exhibit reduced anxiety-like behaviour. Exp Neurol, 210, 788792.

[65] Graham DR, \& Sidhu A (2010) Mice expressing the A53T mutant form of human alpha-synuclein exhibit hyperactivity and reduced anxiety-like behavior. J Neurosci Res, 88, 17771783.

[66] Nuber S, Petrasch-Parwez E, Winner B, Winkler J, von Hörsten S, Schmidt T, Boy J, Kuhn M, Nguyen HP, Teismann P, Schulz JB, Neumann M, Pichler BJ, Reischl G, Holzmann C, Schmitt I, Bornemann A, Kuhn W, Zimmermann F,
Servadio A, \& Riess O (2008) Neurodegeneration and motor dysfunction in a conditional model of Parkinson's disease. $J$ Neurosci, 28, 2471-2484.

[67] Kuo YM, Li Z, Jiao Y, Gaborit N, Pani AK, Orrison BM, Bruneau BG, Giasson BI, Smeyne RJ, Gershon MD, \& Nussbaum RL (2010) Extensive enteric nervous system abnormalities in mice transgenic for artificial chromosomes containing Parkinson disease-associated alpha-synuclein gene mutations precede central nervous system changes. Hum Mol Genet, 19, 1633-1650.

[68] Rockenstein E, Mallory M, Hashimoto M, Song D, Shults CW, Lang I, Masliah, E (2002) Differential neuropathological alterations in transgenic mice expressing alpha-synuclein from the platelet-derived growth factor and Thy-1 promoters. J Neurosci Res, 68, 568-578.

[69] Fernagut PO, Hutson CB, Fleming SM, Tetreaut NA, Salcedo J, Masliah E, \& Chesselet MF (2007) Behavioral and histopathological consequences of paraquat intoxication in mice: Effects of alpha-synuclein over-expression. Synapse, 61, 991-1001.

[70] Fleming SM, Tetreault NA, Mulligan CK, Hutson CB, Masliah E, \& Chesselet MF (2008) Olfactory dysfunction in mice overexpressing human wildtype alpha-synuclein. Eur $J$ Neurosci, 28, 247-256.

[71] Fleming SM, Salcedo J, Fernagut PO, Rockenstein E, Masliah E, Levine MS, \& Chesselet MF (2004) Early and progressive sensorimotor anomalies in mice overexpressing wild-type human alpha-synuclein. J Neurosci, 24, 9434-9440.

[72] Fleming SM, Jentsch JD, \& Chesselet M-F (2011) Cognitive Dysfunction in Genetic Mouse Models of Parkinsonism. In Van Dam D (ed.), Animal Models of Dementia, Neuromethods, Springer: Humana Press, 48, pp. 485-492.

[73] Mulligan CK, Fleming SM, Dorriz P, Masliah E, \& Chesselet M-F (2008) Mice overexpressing human wildtype alpha-synuclein under the Thy-1 promoter exhibit anomalies in behavioral tests of anxiety. Program No. 742.192008 Neuroscience Meeting Planner. Society for Neuroscience, Washington, DC.

[74] Lam HA, Wu N, Cely I, Kelly RL, Hean S, Richter F, Magen I, Cepeda C, Ackerson LC, Walwyn W, Masliah E, Chesselet MF, Levine MS, \& Maidment NT (2011) Elevated tonic extracellular dopamine concentration and altered dopamine modulation of synaptic activity precede dopamine loss in the striatum of mice overexpressing human $\alpha$-synuclein. $J$ Neurosci Res, 89, 1091-102.

[75] Fleming SM, Jordan MC, Masliah E, Chesselet M-F, \& Roos KP (2007) Alterations in baroreceptor function in transgenic mice overexpressing human wildtype alpha synuclein. Program No. 50.9. Neuroscience Meeting Planner. Society for Neuroscience, San Diego, CA.

[76] Fleming SM, Holden JG, Sioshansi PC, Jordan MC, Masliah E, \& Roos KP (2009) Alterations in heart rate variability in transgenic mice overexpressing human wildtype alpha synuclein. Program No. 531.9 Neuroscience Meeting Planner. Society for Neuroscience, Chicago, IL.

[77] Idiaquez J, Benarroch EE, Rosales H, Milla P, \& Ríos L (2007) Autonomic and cognitive dysfunction in Parkinson's disease. Clin Auton Res, 17, 93-98. 